\title{
Cultural competency and nursing care among sundanese nurses ethnic group in Indonesia
}

\author{
Upit Pitriani', Kusman Ibrahim², Sandra Pebrianti2 ${ }^{*}$ \\ ${ }^{1}$ Fakultas Keperawatan, Universitas Padjadjaran, Indonesia. *Email: ufitfitriani01@gmail.com \\ 2Departemen Keperawatan Medikal Bedah, Fakultas Keperawatan, Universitas Padjadjaran, Indonesia. \\ *Corresponding author. E-mail: sandra.pebrianti@unpad.ac.id
}

\begin{abstract}
Background: Nurses as one of the health professionals who are expecting to have competence in providing nursing care to patients based on cultural background.

Purpose: To describe the cultural competency and nursing care among sundanese nurses' ethnic group in Indonesia..

Method: A descriptive design with a quantitative approach. The sampling technique in this study used Cluster Random Sampling with the sample of 63 respondents. The instrument used the NCCS (Nurse Cultural Competence Scale). This research conducted on April 2019 at dr. Slamet Hospital, Garut - Indonesia

Results: Shows that the nurses' cultural competencies in dr. Slamet hospital was in a low category of 37 respondents $(58.7 \%)$. While in a component, cultural awareness was in the low category $(60.3 \%)$, the cultural knowledge component was in the high category $(52.4 \%)$, the cultural sensitivity component was in the low category (58.7\%) and the cultural skills component in the high category $(58.7 \%)$.

Conclusion: The most nurses' cultural competencies was in a low category such as cultural awareness was in the low category $(60.3 \%)$, the cultural sensitivity component was in the low category. Sundanese nurses' ethnic group need to develop training in culturally competent as a local wisdom.
\end{abstract}

\section{Keywords: Cultural competency; Nursing care; sundanese nurses; Ethnic group}

\section{INTRODUCTION}

Nurses in the current era of globalization are required to be professional health workers and have the ability, both intellectual abilities, namely abilities based on intelligence, interpersonal and the ability to interact socially with others. A nurse is expected to have competence with patient culture which includes the ability to respond to cultural diversity in nursing which is very important. Nurses who work in health installations are expected to have cultural competence to ensure quality and safe services are provided.

Cultural competence is a process in which professional service providers continually struggle and achieve the ability to work effectively in the context of the patient's culture (individually, family, or society) (Campinha-Bacote, 2009; CampinhaBacote, 2011; Wilson, 2011).

In Indonesia, the cultural competence of a nurse is still not a concern, most nurses have not prepared their cultural competence during the education process. So the lack of cultural competence of nurses can cause many problems in interacting between nurses and patients. There have been complaints that have emerged as a result of a nurse's lack of concern for the cultural diversity of the patients being treated (Novieastari, et al, 2018; Wijaya, et al, 2018).

Previous research on "Culture-sensitive nursing care training effectively increases the cultural competence of nurses" that a patient who received nursing care from a nurse who had cultural competence, satisfaction with his service was 5.2 times higher compared to patients who were cared for by nurses who had less. Competence (Johnston, 2012; Mirwanti, \& Nuraeni, 2016; Yustisia, et al, 2019).

Nurses in nursing care still focus more on physical needs, the healing process and treatment and less on the cultural aspects of the patient. Even though it is very important for nurses to have knowledge, awareness, skills, and sensitivity to culture and cultural-related competencies to improve the quality of nursing care to patients according to their cultural background. In Indonesia there is still little research on the cultural 
competence of nurses, so researchers are interested in conducting research on the description of the cultural competence of nurses in dr. Slamet Garut Hospital.

\section{RESEARCH METHODS}

A descriptive study, with a quantitative approach. The population in this study were nurses in Dr. Slamet Garut hospital with a population of all sundanese staff nursing at 11 inpatient wards. The sampling technique used cluster random sampling with a sample size of 63 respondents. The instrument used the NCCS (Nursing Cultural Competence Scale instrument (Perng, \& Watson, 2012; Loftin, 2013; Cruz, et al, 2016). Which consists of four components in the competency process such as cultural awareness, cultural knowledge, cultural sensitivity and cultural skills Alternative answer choices use a Likert scale, the value of cultural competence is high if it is more than the mean, while it is a category of cultural competence is low if it is less than the mean. The nurses' staff on duty inpatient wards willing to be a respondent. The researcher will present the data then group them as a percentage using a frequency distribution regarding the cultural competence of nurses, namely high cultural competence and low cultural competence, the researcher will add up the scores and averages of each domain and calculate the mean value because in order to make the basis for dividing high/ low, and a percentage made by the number of respondents divided by the total number of respondents then multiplied by $100 \%$.

\section{RESULTS}

Table 1. Demographic Characteristics of Respondents ( $\mathrm{N}=63)$

\begin{tabular}{lccc}
\hline Demographic & Frequency (f) & Percentage (\%) & M $\mathbf{S D}$ \\
\hline Age (Years) (Range: 23-53) & & & $37.70 \pm 8.185$ \\
& & & $11.73 \pm 5.052$ \\
Duration of Employ (Years) & & & \\
(Range: 1-21) & & & \\
Gender & 36 & 57.1 & \\
Female & 27 & 42.9 & \\
Male & & & \\
Educational Level & 11 & 17.5 & \\
Diploma Degree & 13 & 20.6 & \\
Bachelor Degree & 38 & 60.3 & \\
Ners Degree & 1 & 1.6 & \\
Graduate Degree & & & \\
\hline
\end{tabular}

Based on table 1, the characteristics of respondents aged between 23 years up to 53 years with a mean of 37.70 and a standard deviation of 8.185. and duration of employ between a year up to 21 years with a mean of 11.73 and a standard deviation of 5.052. mostly female of 36 respondents $(57.1 \%)$, the education level of most of Ners degree was 38 respondents (60.3\%).

Upit Pitriani , Fakultas Keperawatan, Universitas Padjadjaran, Indonesia. Email: ufitfitrianioı@gmail.com Kusman lbrahim, Sandra Pebrianti*, Departemen Keperawatan Medikal Bedah, Fakultas Keperawatan, Universitas Padjadjaran, Indonesia. ${ }^{*}$ Corresponding author. E-mail: sandra.pebrianti@unpad.ac.id 
Table 2 The Cultural Competence of Nurses $(\mathrm{N}=63)$

\begin{tabular}{lcccc}
\hline The Cultural Competence & Frequency (f) & Percentage (\%) & Mean & SD \\
\hline High & 26 & 41.3 & 160.49 & 9.658 \\
Low & 37 & 58.7 & & \\
\hline
\end{tabular}

Based on table 2 the description of the results of the total components of cultural competence, most of the 37 respondents $(58.7 \%)$ were in the low cultural competency category while those assessed as high cultural competence only reached 26 respondents $(41.3 \%)$.

Table 3 Components of The Cultural Competence $(\mathrm{N}=63)$

\begin{tabular}{lcccc}
\hline Components of Cultural Competence & Frequency (f) & Percentage (\%) & Mean & SD \\
\hline $\begin{array}{l}\text { Cultural Awareness } \\
\quad \text { High }\end{array}$ & 25 & 39.7 & 40.40 & 3.925 \\
$\quad$ Low & 38 & 60.3 & & \\
Cultural Knowledge & & & & \\
$\quad$ High & 33 & 52.4 & 35.65 & 2.37 \\
$\quad$ Low & 30 & 47.6 & & \\
Cultural Sensitivity & & & & \\
$\quad$ High & 26 & 41.3 & 29.41 & 3.201 \\
$\quad$ Low & 37 & 58.7 & & \\
$\quad$ Cultural Skills & & & & \\
$\quad$ High & 26 & 58.7 & 55.03 & 3.797 \\
$\quad$ Low & 37 & 41.3 & & \\
\hline
\end{tabular}

Based on table 3 shows the cultural component in the low category such as cultural awareness component $(60.3 \%)$ cultural sensitivity component $(58.7 \%)$.

\section{DISCUSSION}

Cultural competence is a process in which the provision of services in providing nursing care is based on the attitude of a nurse who has the ability, knowledge and skills to work effectively in cross-cultural situations by looking at the cultural context which consists of cultural awareness, cultural knowledge, cultural sensitivity. and cultural skills, so that the provision of quality nursing services to patients who have a variety of cultures (Perng, \& Watson, 2012; Dudas, 2012; Shen, 2015).

Based on the results of the frequency distribution and percentages described in table 1 . regarding the cultural competence of nurses in dr.Slamet Garut Hospital, it was found that of the four components of cultural competence, 37 respondents were in the low cultural competency category and 26 respondents had high cultural competence.

This is supported by the results of previous research that clinical nurses must apply nursing interventions to patients with legal and ethnic attention to improve the competence and careers of nurses, but in this study it was seen that some clinical nurses in carrying out nursing care were still not optimal and needed guidance, in particular. professional development such as training and further education (Eldest, 2016; Suprapti, 2019).

This condition is caused by nurses who do not have experience and a working period of less than ten years and have not received training in the last three years and the concept of career development to improve competence is not understood by each nurse. The results of the frequency distribution and presentation regarding the components of cultural awareness were in the low category as many as 38

Upit Pitriani , Fakultas Keperawatan, Universitas Padjadjaran, Indonesia. Email: ufitfitrianioı@gmail.com

Kusman lbrahim, Sandra Pebrianti*, Departemen Keperawatan Medikal Bedah, Fakultas Keperawatan, Universitas

Padjadjaran, Indonesia. ${ }^{*}$ Corresponding author. E-mail: sandra.pebrianti@unpad.ac.id 
respondents $(60.3 \%)$. The results of the research on low cultural awareness are found in items, one of which is that nurses do not agree that nursing education items are a cultural system, maybe because nurses think that nursing does not only see a person from their culture but is seen as a whole starting from their biopsychosocial and spiritual.

This research is supported by the results of research conducted in China concerning Identifying the essential components of cultural competence in a chinese nursing context with the result that cultural awareness in China focuses on cultural recognition, because the term culture seems too abstract for Chinese nurses, even though nursing has become a discipline. academics that have been recognized but nursing education still follows a medical education model that tends to be disease-oriented (Cai, et al, 2017).

The application of culture in nursing education at the DIII and undergraduate level has not been a concern, the respondents stated that cultural education must be considered and that cultural training for nurses should be further enhanced to increase cultural awareness and how nurses provide services in accordance with patient culture. Cultural awareness is widely recognized by nurses but only to know himself to gain understanding and to realize that in serving the patient's cultural diversity but in this study the cultural awareness of nurses is still lacking to prepare culturally competent nurses (Adam, 2013). The results of the frequency distribution and presentation of cultural knowledge were in the high category as many as 33 respondents $(52.4 \%)$. The results of the research from cultural knowledge that the highest average were in the item that nurses knew and understood social and cultural factors affecting health and disease, for example, nurses had to know that the culture of each patient was the same ethnicity but the habits regarding disease healing were definitely different. High knowledge of nursing culture can also be related to the level of education of a nurse, because in this study, based on the latest education, most of them were educated professionally as many as 38 respondents (60.3\%).

Most of the nurses in this study were educated at the latest Ners education, different from previous research on the relationship between knowledge and attitudes of nurses in providing nursing care, explaining that the results of the research conducted on the respondents were mostly nurses who were graduates of the Nursing Academy, because the demands of the professional world of nursing were at least a beginner professional education Academy of Nursing and better if the nurse has a minimum education of Bachelor+Ners (Utami, 2009; Yaseda, 2013). This case it can be concluded that the higher the level of education of hospital nurses can affect the level of performance of nurses in providing nursing care to meet the basic needs of patients and increase nurse competence. The results of the frequency distribution and presentation regarding cultural sensitivity are in the low category with an average of 37 respondents $(58.7 \%)$. The lowest item in the component of cultural sensitivity is found in the item, namely if the patient uses a treatment method that is different from the professional experience of nurses usually will not be prohibited, why is this item the lowest, maybe because nurses should not prohibit someone's culture but provide health or understanding to the family about this. he will do or in making decisions for the patient's treatment. Cultural sensitivity is the right direction nurses take with culturally diverse patients and highlights openness.

Nonjudgmentaland mutual respect. Low cultural sensitivity may not have anything to do with gender, because the results showed that most of the women were 36 respondents $(57.1 \%)$. There are more nurses who serve in the Inpatient Room of the Dr. Slamet Garut Hospital, more women than men.

Based on research on culturally sensitive nursing care training, it is effective to increase the cultural competence of nurses, it explains that men are more practical than female nurses who have advantages in terms of accuracy, tenderness, patience, responsiveness, instincts in educating, caring for, serving, caring for and providing services health, thus it can be concluded that the cultural competence of nurses is more dominant to female nurses so there is no relationship between female nurses and the cultural sensitivity of nurses to patients with different cultural backgrounds (Novieastari, et al, 2018).

The frequency distribution and presentation regarding the cultural skills of nurses were in the low category as many as 37 respondents $(58.7 \%)$. The highest item of cultural skills is that nurses can teach and guide students nursing to show appropriate behavior when they apply nursing care

Upit Pitriani , Fakultas Keperawatan, Universitas Padjadjaran, Indonesia. Email: ufitfitrianiol@gmail.com

Kusman lbrahim, Sandra Pebrianti*, Departemen Keperawatan Medikal Bedah, Fakultas Keperawatan, Universitas Padjadjaran, Indonesia. *Corresponding author. E-mail: sandra.pebrianti@unpad.ac.id 
to patients from various cultures, in addition to being health workers, nurses must also have skills as guides in the practical field. The skills of a nurse are not only in nursing actions but must be skilled in communicating with patients from various cultural backgrounds. Nurse's cultural skills are related to age, education and length of work.

Nurses in this study were of productive age, where the age range was between 31-40 years. At this age nurses can have the ability to carry out regular activities (National Population and Family Planning Agency, 2013; Susanti, 2015). Research on "Identifying the essential components of cultural competence in a Chinese nursing context" explains that the average age of respondents is 39 years, this age has a relationship between the age of the nurse and the length of work and the cultural competence of nurses because the increasing age of nurses, the length of their work is also increase (Cai, et al, 2017; Hadziabdic, et al, 2016).

The data obtained by the researchers indicated that the age range of respondents ranged from 27 years to 49 years. Thus, nurses in carrying out nursing care to patients were able to adjust their actions according to their age. It can be concluded that the age of nurses and the length of time working in providing nursing care has a relationship in order to work effectively, the higher the level of education of hospital nurses can affect the level of performance of nurses in providing nursing care to meet the basic needs of patients and increase nurse competence. Conclusion Nursing cultural competence is a process where the provision of nursing services must be continuous and can achieve the ability to work effectively across patient cultures, both individuals, families and communities. The competencies that must be possessed by a nurse are cultural awareness, cultural knowledge, cultural sensitivity and cultural skills. Based on the results of the research conducted, it can be concluded that thecompetence culturalof the most dominant nurses who have high results is in the cultural knowledge component, while the dominant domain that has low results is in the components of cultural awareness and cultural sensitivity and cultural skills, so that the cultural competence of nurses is still present. in the low category.

\section{CONCLUSION}

The cultural competence among sundanese nurses finding in some component cultural competence in a low category in providing nursing care to patients. The hospital management can provide training such as therapeutic communication training for nurses to have competence with patient culture, have an awareness of patient culture, knowledge, patient cultural skills in providing nursing care and not only focus on physical examination, treatment, and their physical needs.

The Nursing Practitioners Based on evidence, the researcher suggests nurses to increase their competence in providing nursing services based on behavior, attitudes and awareness in providing services to patients based on different cultural backgrounds and respecting and respecting patient cultural differences. The nursing Educators Based on eviden, it is hoped that nursing educators can use this thesis as a reference for Nursing Students and the Nursing Institution itself. This research can also be used by professional nurse students in terms of increasing cultural competence when they enter the hospital field to improve the performance of a nurse. For Further Researchers Based on the results of the above research, further researchers are expected to be able to examine in terms of Cultural Competency Training in an affective way and be able to carry out the same research using an instrument that contains an assessment of the competence of the nurse itself which is carried out by observation.

\section{REFERENCES}

Adam, R. A. (2013). Pengembangan Budaya Organisasi Keperawatan Untuk Meningkatkan Kinerja Dan Kepuasan Perawat Dalam Penerapan Metode Asuhan Keperawatan Profesional Di Rumah Sakit (Doctoral dissertation, Universitas Airlangga http://repository.unair.ac.id/32872/2/F9.pdf

Cai, D., Kunaviktikul, W., Klunklin, A., Sripusanapan, A., \& Avant, P. K. (2017). Identifying the essential components of cultural competence in a Chinese nursing context: $A$ qualitative study. Nursing \& Health Sciences, 19(2), 157-162. https://onlinelibrary.wiley.com/doi/pdf/10.1111/n $\underline{\text { hs. } 12308}$

\footnotetext{
Upit Pitriani, Fakultas Keperawatan, Universitas Padjadjaran, Indonesia. Email: ufitfitrianiol@gmail.com Kusman lbrahim, Sandra Pebrianti*, Departemen Keperawatan Medikal Bedah, Fakultas Keperawatan, Universitas Padjadjaran, Indonesia. *Corresponding author. E-mail: sandra.pebrianti@unpad.ac.id
} 
Campinha-Bacote, J (2009). A culturally competent model of care for African Americans. Urologic Nursing, 29(1), 49. https://www.suna.org/download/members/unjart icles/2009/09feb/49.pdf

Campinha-Bacote, J. (2011). Delivering patientcentered care in the midst of a cultural conflict: The role of cultural competence. The Online Journal of Issues in Nursing, 16(2). https://ojin.nursingworld.org/MainMenuCategori es/ANAMarketplace/ANAPeriodicals/OJIN/Tabl eofContents/Vol-16-2011/No2-May2011/Delivering-Patient-Centered-Care-in-theMidst-of-a-Cultural-Conflict.aspx

Cruz, J. P., Estacio, J. C., Bagtang, C. E., \& Colet, P. C. (2016). Predictors of cultural competence among nursing students in the Philippines: A cross-sectional study. Nurse Education Today, 46, 121-126. https://www.sciencedirect.com/science/article/a bs/pii/S0260691716301939

Dudas, K. I. (2012). Cultural competence: An evolutionary concept analysis. Nursing Education Perspectives, 33(5), 317-321. https://journals.Iww.com/neponline/Abstract/201 2/09000/CULTURAL COMPETENCE An Ev olutionary_Concept.8.aspx

Hadziabdic, E., Safipour, J., Bachrach-Lindström, M., \& Hultsjö, S. (2016). Swedish version of measuring cultural awareness in nursing students: validity and reliability test. $B M C$ nursing, 15(1),

https://link.springer.com/article/10.1186/s12912 -016-0146-6

Johnston, H. E. (2012). Increasing Nurses' Awareness of Spiritual and Cultural Diversity in Health Care. Journal of Obstetric, Gynecologic \& Neonatal Nursing, 41, S118. https://onlinelibrary.wiley.com/doi/pdf/10.1111/j. 1552-6909.2012.01361_99.x

Loftin, C., Hartin, V., Branson, M., \& Reyes, H. (2013). Measures of cultural competence in nurses: An integrative review. The Scientific World Journal, 2013. https://www.hindawi.com/journals/tswj/2013/28 $\underline{9101 /}$
Novieastari, E., Gunawijaya, J., \& Indracahyani, A. (2018). Pelatihan asuhan keperawatan peka budaya efektif meningkatkan kompetensi kultural perawat. Jurnal Keperawatan Indonesia, 21(1), 27-33. https://doi.org/10.7454/jki.v21i1.484

Mirwanti, R., \& Nuraeni, A. (2016). Hubungan Kesejahteraan Spiritual dengan Depresi pada Pasien dengan Penyakit Jantung Koroner (PJK). MEDISAINS, 14(1).

http://jurnalnasional.ump.ac.id/index.php/medis ains/article/viewFile/1044/2139

National Population and Family Planning Agency (2013). Survey demografi dan kesehatan Indonesia (SDKI) 2012. Jakarta: BKKBN

Perng, S. J., \& Watson, R. (2012). Construct validation of the nurse cultural competence scale: A hierarchy of abilities. Journal of Clinical Nursing, 21(11-12), 1678-1684. https://onlinelibrary.wiley.com/doi/epdf/10.1111/ j.1365-2702.2011.03933.x

Shen, Z. (2015). Cultural competence models and cultural competence assessment instruments in nursing: a literature review. Journal of Transcultural Nursing, 26(3), 308-321. https://journals.sagepub.com/doi/full/10.1177/1 $\underline{043659614524790}$

Sulung, N. (2016). Efektifitas Metode Preseptor dan Mentor dalam Meningkatkan Kompetensi Perawat Klinik. Jurnal Ipteks Terapan, 9(2), 224-235.

https://pdfs.semanticscholar.org/2e95/b9061af1 be54b8d2b051c2006cca57763d29.pdf

Susanti, H. A. (2015). Strategi komunikasi badan kependudukan dan keluarga berencana nasional (bkkbn). Jurnal ASPIKOM, 2(4), 243254.

http://jurnalaspikom.org/index.php/aspikom/artic $\underline{\text { le/view/75/73 }}$

Suprapti, S. (2019). Analisis Dampak Model Pelatihan Klasikal dan Preseptorsip terhadap Kompetensi terhadap Kompetensi serta Capaian Kompetensinya (Studi Kuasi Eksperimental di RSAB Harapan Kita). Jurnal IImiah Administrasi Publik, 5(2), 196-206.

Upit Pitriani , Fakultas Keperawatan, Universitas Padjadjaran, Indonesia. Email: ufitfitrianiol@gmail.com

Kusman lbrahim, Sandra Pebrianti*, Departemen Keperawatan Medikal Bedah, Fakultas Keperawatan, Universitas Padjadjaran, Indonesia. *Corresponding author. E-mail: sandra.pebrianti@unpad.ac.id 
https://jiap.ub.ac.id/index.php/iiap/article/view/81 $\underline{2 / 1225}$

Utami, Y. W. (2009). Hubungan Antara Pengetahuan Dengan Sikap Perawat Dalam Pemenuhan Kebutuhan Spiritual Pasien Di BRSUD

Sukoharjo.https://publikasiilmiah.ums.ac.id/xmlu i/handle/11617/2039

Wijaya, F. R., Prastiwi, S., \& Dewi, N. (2018). Hubungan Komunikasi Terapeutik dengan Ketepatan Pemberian Obat Pada Pasien Rawat Inap di RS Panti Waluya Sawahan Malang. Nursing News: Jurnal IImiah Keperawatan, 3(3).

https://publikasi.unitri.ac.id/index.php/fikes/articl e/viewFile/1374/959

Wilson, L. D. (2011). Cultural competency: Beyond the vital signs. Delivering holistic care to african americans. Nursing Clinics, 46(2), 219-232. https://www.nursing.theclinics.com/article/S002 9-6465(11)00008-9/abstract
Yaseda, G. Y., Noorlayla, S. F., \& Efendy, M. A. A. (2013). Hubungan Peran Perawat Dalam Pemberian Terapi Spiritual Terhadap Perilaku Pasien Dalam Pemenuhan Kebutuhan Spiritual Di Ruang ICU RSM Ahmad Dahlan Kota Kediri. STRADA Jurnal IImiah Kesehatan, 2(2), 41-49.

https://www.sjik.org/index.php/sjik/article/view/5 $\underline{3 / 57}$

Yustisia, N., Aprilatutini, T., \& Rizki, T. D. (2019). Gambaran Kesejahteraan Spiritual pada Pasien Chronic Kidney Disease di Rsud dr. M. Yunus Bengkulu. Jurnal Vokasi Keperawatan (JVK), 2(1), 43-52. https://ejournal.unib.ac.id/index.php/JurnalVoka siKeperawatan/article/view/10653/5265

Upit Pitriani , Fakultas Keperawatan, Universitas Padjadjaran, Indonesia. Email: ufitfitrianioı@gmail.com 